\title{
There Will be no Strength (In)coherence and (Im)potency
}

In the volume King Popiel and other Poems Miłosz published a text, which is particularily interesting yet very rarely read by his commentators. If only for this reason Rescue is an unusual poem. There are several elements composing the uniqueness of this poem. First, it is the geographical location of the lyrical situation: the poem, if I may put it that way, "happens" at the end of the 1940s in Wroclaw. In a sense it is a poem about post-WWII Wroclaw.

If not for this work, Wroclaw wouldn't be included in the poetic "cities atlas" of Czesław Miłosz. It is easy to mark off the literary production of Miłosz' urban mini-cycles, gathering Vilnius, Cracow, Warsaw, Paris and Washington poems (that is, poems written in those cities, which is revealed frequently in paratextual notes describing the mentioned cities). The author of City Without a Name, who authored the phrase "Cities, you have not been described", is an architect of his own "geopoetics", followed carefully by literary scholars: the Warsaw of Miłosz became a subject of a different, collective monography ${ }^{1}$, the Vilnus of Miłosz ran a beautiful study in a book written by Wojciech Ligęza ${ }^{2}$,about Miłosz in Cracow (and Cracow in Miłosz's texts) wrote Marta Wyka ${ }^{3}$,Beata Tarnowska became interested in the Paris of Miłosz $z^{4}$. The Wroclaw of Miłosz exists because of one poem.

\footnotetext{
* Ph.D., Jagielonian University, Faculty of Polish Studies, Katedra Historii Literatury Polskiej XX wieku; e-mail: mateusz.antoniuk@uj.edu.pl.

${ }^{1}$ Warszawa Miłosza, M. Zaleski (ed.), IBL PAN, Warsaw 2013.

${ }^{2}$ W. Ligęza, Jerozolima i Babilon. Miasta poetów emigracyjnych, Wydawnictwo Baran i Suszczyński, Cracow 1998, pp. 58, 106-107, 233-246. The erudite study of Wojciech Ligęza brings more comments dedicated to the aspects of Miłosz's "urban geopoetic" different than the Vilnius ones.

${ }^{3} \mathrm{M}$. Wyka, Dom literacki jako imago mundi. Wokół krakowskiego epizodu Czesława Miłosza, "Dekada Literacka" 2011, issue 1/2; eadem, Miłosz i rówieśnicy. Domknięcie formacji, Universitas, Cracow 2013, pp. 196-201.

${ }^{4}$ B. Tarnowska, Geografia poetycka w powojennej twórczości Czesława Miłosza, Wyższa Szkoła Pedagogiczna, Olsztyn 1996.
} 
Andrzej Franaszek associated the creation of Room with a short visit of the poet to the capital of Lower Silesia in 1949. The author of Rescue and The Moral Treaty came then to Poland from the United States for a stay of several months, holding various meetings with his readers - one of which was a meeting in Wroclaw $^{5}$.If this poem is indeed a reminiscence of that event, the temporal distance between the experience and the text is surprising. Miłosz wrote Room in $1955^{6}$, and it was not until 1961 that he published it, more than ten years after his short visit by the Oder. There must had been a vital reason for which the poet returned to a receding time and place, the memory of his stay in Wroclaw must had been tied to a strong, eloquent experience. Room, despite some pretences of flatness, and a unique articulary negligence, is undoubtedly a strong, intense poem. Franaszek called it "a study of alienation, not less than that one, which the poet saw in Detroit and described in a work entitled There is no sight". It is an interesting association. Both poems are set in a hotel, in a kind of a non-place, characterized by transivity, temporariness, rootlessness ${ }^{7}$. Nevertheless, the Wroclavian poem seems to be (in my opinion) a much more interesting work or language game than the American one. I will try to look at that work and this game as attentively as possible.

The poem reads as follows:

\author{
Room \\ $\mathrm{W}$ ciemnym hotelu \\ W mieście Wrocławiu \\ Zapach ruiny \\ Starte chodniki \\ Łyżeczki w szklance \\ $\mathrm{Na}$ korytarzu \\ Szła numerowa \\ Starte chodniki.
}
[In a dark hotel
In the city of Wroclaw
the smell of the ruin
worn pavements
spoons in the glass
in a hall
the porter was passing
Worn pavements

${ }^{5}$ See. A. Franaszek, Miłosz. Biografia, Znak, Cracow 2011, pp. 427, 830.

${ }^{6}$ At least - such a date is visible below the text published in a volume of poetry.

${ }^{7}$ A. Franaszek, op. cit., p. 830. Tracking quoted observations, one can add that this peculiar "hotel diptych" (the poem about Detroit - 1949, the poem about Wroclaw - 1955) finds its late elaboration or complement in a short lyric, which belonged to the $O$ ! series and made an interpretation of Edward Hopper's painting entitled Hotel room. M.P. Markowski wrote about the last mentioned work in an essayistic-polemical mode on the pages of a book entitled Słońce, możliwość, radość, Czarne, Wołowiec 2010, pp. 87-89; cf. also interesting commentary to the poem by Miłosz and footnotes by Markowski: E. Sawicka, Hopper w Muzeum Thyssen-Bornemisza, "Zeszyty Literackie” 2012, issue 4, p. 282. 
Klucz się przekręca

W pokoju obok

Trzasnęło światło

Echo i głosy

Zgasili światło

I łóżko skrzypi

W ciemnym hotelu

Starte chodniki.

Pewnie służbowo

Tutaj z Warszawy

I ekspedientka

Z państwowych sklepów

Zapach ruiny

Zegar na wieży

Czerwień o zmierzchu

I łóżko skrzypi.

Oceaniczne

Plantacje piany

Góry lodowe

Płyną pode mną

To jest po wojnie

Połowa wieku

Huczą kolibry

Popiół popiołów.

Huczą kolibry

Jak mam udźwignąć

Okrągłą ziemię

Która się toczy

We mnie i woła

Lądami swymi

Morzami swymi

Żeby udźwignąć.

Nowa Fundlandia

Zamarzła brzoza

Piany przy wyspach

Szczekają foki

Czerwień o zmierzchu
The key is turning

in the next room

the light crackled

Echo and voices

They switched the light off

And the bed is creaking

In a dark hotel

Worn pavements

Probably on business

Here from Warsaw

And a shop assistant

from state shops

Smell of the ruins

Clock on the tower

Redness in the dusk

And the bed is not creaking.

Oceanic

Foam plantations

Icebergs

are flowing beneath me

That is after the war

half of the century

Humming birds are hooting

Ash of the ashes.

Humming birds are hooting

How am I supposed to bear

the round earth

which rolls

In me and calling

With its lands

its seas

To bear.

Newfundlands

Frozen birch

Foams by the islands

Seals are barking

Redness in the dusk 
Ptaki na grobach

Dwoje za ścianą

Strzaskane płyty.

Bęben i trąba

Przez megafony

Słuchali oddech

Ziemia się toczy

I nie zdołali

Nie będzie siły

Ciężka jak serce

Żeby udźwignąć.

Nie wiem czy litość

Nie wiem czy miłość

Zamarzła brzoza

Łóżko nie skrzypi

Bądź mi do końca

Połowa wieku

Ciężka jak serce

Starte chodniki.
Birds on the tombs

The two behind the wall

Shattered slabs.

Drum and horn

through megaphones

They listened to the breath

The earth is rolling

And they did not manage

There will be no strength

Heavy as a heart

To bear.

I do not know whether pity

I do know know whether love

Frozen birch

The bed is not creaking

Be thou until the end

Half of the century

Heavy as a heart

Worn pavements]

Brie-Comte-Robert, 1955

The first stanza introduces the reader to the centre of disturbing, pessimistic worldness. We are - along with an subject talking to us, together with a "numerical", whose steps are heard through the door of the room - in such a place in the world, in an area of reality, where the world, where reality is experienced as wasted, worn out, weak matter. By this I mean: either it is already subjected to destruction, subjugated to disaster ("smell of ruin"), or gradually decreasing, wending to decline ("worn pavements").

Within an area endangered by consumption, decay, depletion, mediocrity of the weakening matter and human aspirations, attempts and efforts take place. The world (perceived-imagined - shown) undergoes progressive impairment and corruption but in an impaired and corrupted world there exists a will contrary to this tendency - the will of acting. We can read about it first in the second stanza:

Klucz się przekręca

W pokoju obok

Trzasnęło światło

Echo i głosy

Zgasili światło

I łóżko skrzypi
[The key is turning

in the next room

the light crackled

Echo and voices

They switched the light off

And the bed is creaking] 
and in the fifth stanza afterwards:

Jak mam udźwignąć

Okrągłą ziemię

Która się toczy

We mnie i woła

Lądami swymi

Morzami swymi

Żeby udźwignąć.
[How am I supposed to bear

the round earth

which is rolling

In me and calling

With its lands

its seas

To bear.]

The first of the quotations tells about an action, which has already been taken; the other deals with an action that is a matter of expectation and concern. What are these actions?

The first one is obvious: a couple behind the wall are going to engage in a sexual act. The second action is definetely much less clear and was encoded in a metaphorical formula: "bear the earth". What does it mean? Take responsibility for the earth? What a megalomaniac ambition - does the subject feel some saviourous commitments? Or maybe: imagine the world, understand it, grasp as many matters as possible? Or (where both speculations formulated above would be included) carrying the earth is here a pseudonym for the procedure of describing, expressing and presenting. It is this option which seems to me the most interesting and the most promising for the interpretation of Room's interpretation, therefore I assume that another initiative (apart from the erotic one) undertaken "in a dark hotel in the city of Wroclaw" is an attempt to create a linguistic representation of the world. In other words, a mimetic total act presenting the entirety of reality in its essence and burden. If so, then it would seem that in the fifth stanza of Room we find the realisations of two metapoetical topoi wandering through various poems by Miłosz. The phrase about the earth demanding from the persona "bearing" we can hear now as another draft of the representation, in which reality is thirsty for naming, expressing and expects its new mouthpiece - a poet ${ }^{8}$. An interrogative exclamation "How am I supposed to bear" should be acknowledged as another rhetorical expression of doubt in the possibility or fidelity in the linguistic image of the world.

Therefore: a work of eroticism and work of poietics (that is, etymologically speaking, the art of producing: texts, representations, meanings, cf. Greek poiesis

\footnotetext{
${ }^{8}$ Such a projection is established for example in Dithyramb from 1938 (I wrote more about this poem in the third part of the book) or To Tadeusz Różewicz, the poet from 1948: "Zgodne w radości są wszystkie instrumenty, / Kiedy poeta wchodzi w ogród ziemi. [...] Więc się radują wszystkie instrumenty / Zamknięte w pudłach i dzbanach zieleni, / Czekając, aby dotknął i aby zabrzmiały." ("Unanonimous are in joy all the instruments / When The poet enters to the garden of the earth / [...] So all the instruments are overjoyed / closed in their boxes and jars of the green/ waiting for him to touch them and resound").
} 
- production, poiein - produce). Miłosz was apparently set on creating an analogy between these actions, intentionally located next to each other, in the same place and at the same time. Both happen simultaneously, separated only with a tiny partition, as if it was a simultaneous scene. The couple behind the wall looks for erotic fullfillment. Language seeks a possibility of expressing the earth with its seas, continents, the destroyed city of Wroclaw, the scruffy hotel... and the couple behind the wall.

What does the work of eroticism consist in? To see it clearly, one should use the indiscretion of the text, which in preserving the anonymity as to the personal details of the main protagonists of the love story does not begrudge sociological advice. If it comes to "the truth behind the wall" one knows that "he" came to Wroclaw on business from Warsaw, that "she" is a shop assistant working in a state shop. She works in the city, so she is probably not a stranger. Nevertheless, what does it mean not to be a stranger in Wroclaw, at the end of the 1940s, "directly after the war"? The woman from behind the wall can be visualized as a stranger, newly settled in an unknown community. She can be a repatriated person but also somebody who came from the country to the city, taking advantage of the opening channels of social mobility. Here, I wish to make a reservation: by no means do I practise a naive, reduntant sociologal reading of the poem. I do not add any sub-plot, on the contrary: I attempt to identify signals which are given by the poem. In the end, Miłosz extensively exposed Wroclaw conditions and he was anxious that we know and remember that this action did not take place in this disturbed, post-war city without a name but in Wroclaw. And certainly the author deliberately emphasized the nomadic status of the male protagonist. These circumstances induce serious treatment of Wroclaw reality and enable us to understand that the work of the erotic will consist of establishing a short but physically intensive, close relationship between uprooted, relocated people. People who were found in the city and a hotel "from nowhere" 9 .

When the "force joining men and women into the Shakespearean animal with two backs" ("spajająca mężczyzn i kobiety w szekspirowskiego zwierza o dwóch plecach"), becomes released ${ }^{10}$ in the mind of the poet who tries to "carry

${ }^{9}$ Incidentally: the topic of erotic relationships in a post-war city in the so-called Recovered Territories returns in a very interesting way in the latest Polish prose; I mean the Szczecin dilogy by Inga Iwasiów (Bambino, 2008; Towards the Sun, 2010). The erotic situations and love affairs are between relocated people who were stripped of their previous social-cultural contexts.

${ }^{10}$ I am paraphrasing the excerpt of the poem Language was changing, written 6 years later than Room and included into book of poems Gucio enchanted: "I siła, która spaja mężczyzn i kobiety / W szekspirowskiego zwierza z dwojgiem pleców, / Pozostaje sprawą ciemną, jakiekolwiek nada się imiona" (And the strength which joins the men and women / In shakespearean animal with two backs". The "Shakespearean animal" refers to Otello. In scene I, act I of this tragedy Iago turns to Brabanzio saying: "your daughter and the Moor are now making the beast with two backs"; Polish translation: "twoja córka i murzyn tworzą teraz zwierzę o dwóch grzbietach" (J. Paszkowski); "córka twoja i Maur sprzęgli się teraz w zwierzę o dwu grzbietach” (M. Słomczyński). 
the earth" continously integrates the text conceived as a representation of extratextual reality. For a lover of linguistic analyisis such an integration is an intriguing phenomenon - let us look closer, probing the sixth stanza:

\author{
Nowa Fundlandia \\ Zamarzła brzoza \\ Piany przy wyspach \\ Szczekają foki \\ Czerwień o zmierzchu \\ Ptaki na grobach \\ Dwoje za ścianą \\ Strzaskane płyty.
}

\author{
[Newfoundlands \\ Frozen birch \\ Foams by the islands \\ Seals are barking \\ Redness in the dusk \\ Birds on the tombs \\ The two behind the wall \\ Shattered slabs.]
}

The association between the last, rhyme line of the quoted stanza with the seven preceding lines was not finally decided, which is responsible for the peculiar, consistently whimsical textual composition. Room is the only printed poem by Miłosz with such an aberrant distribution of punctuation marks: preserving full stops of closing stanzas, with a persistent lack of full stops, comas, dashes, colons or semicolons at the end and in the middle of all "not final" lines. There are capital letters - but in the beginning of each line without exception, thereby completely deprived of distinctive power, incapable of playing the retrospective roles of syntactic delimitation signs. As a result, the textual coherence is built in a magnificient, idiomatic way, which is silhouetted against other poems of the author of City without a name.

One can assume that the expression included in the eighth line is included in a sequence of enumeration based on the associative editing with not entirely clear construction - "shattered slabs" will specify some actually shattered slabs, something damaged, that the poetic subject thought about when creating a textual representation of reality. The text offers an opportunity for such a reading, in which the expression "shattered slabs" will come into logical connections with other phrases from the sixth stanza. There are at least two open options of specification (and two reconstructions of half-erased punctuation):

Ptaki na grobach (.)

Dwoje za ścianą (:)

Strzaskane płyty.

or:

Ptaki na grobach

(-) Dwoje za ścianą (-)

Strzaskane płyty.
[Birds on the tombs

The two behind the wall

Shattered slabs.]

[Birds on the tombs

The two behind the wall

Shattered slabs.] 
In the first interpretation, the phrase's meaning is a result of a periphrasis describing the condition of the protagonists of the erotic plot: "he" and "she" in next room are as "shattered slabs". In the second example, the middle line was treated as an interpolation, above which there is a semantic communication of "birds on the tombs" and "shattered slabs". In this situation, the word "slab" can be specified semantically as "gravestone" - the rhyme phrase would be concerned with developing the plot and the image of a grave. If Miłosz, as he did from his first to last volume, had been accurate when it came to punctuation, the syntactic shape of this stanza would be better, and would probably limit the mobility and venturous nature of the words which negotiate with each other. However, Miłosz intentionally resigned from such conceived constructive coherence: supposed intra-line parenthesis remained as an unconfirmed possibility but was also released in a logical, grammatical and graphic way.

Suppose one proposed a third interpretation of the sixth stanza? Below, using underlining, I am marking expressions which can be associated in a common entity of meaning:

\author{
Nowa Fundlandia \\ Zamarzła brzoza \\ Piany przy wyspach \\ Szczekają foki \\ Czerwień o zmierzchu \\ Ptaki na grobach \\ Dwoje za ścianą \\ Strzaskane płyty.
}

\author{
[Newfoundlands \\ Frozen birch \\ Foams by the islands \\ Seals are barking \\ Redness in the dusk \\ Birds on the tombs \\ The two behind the wall \\ Shattered slabs.]
}

Did the poet predict such a possibility? Probably not but it is impossible to prove it either way. So, does the last suggestion reflect the freedom of misinterpretation? I do not think that it could be a correctly formulated objection. I am multiplying the possibilities of the ambiguous reconcilement of the sixth stanza and the communicative conbination of the last line, not only on my own initiative, but because of the consent, even textual provocation by the author, who organised this text as he did. The shortage of punctuation in the closing lines allows the attentive reader to see the initial-ryhme correspondence of the text. An arctic, frigid, wintry context, moved from the opening couplet to the closing line allows the "shattered slabs" to become more specific in reading as ice tiles, smashing each other, breaking ice floes.

Semantic possibilities that have been already mentioned can be treated as equal elements of an alternative and "switched" readings of the stanza (as well as the whole poem) into different or contrary lines, as moments of one reading, moments, which can be combined or added up. Such a "cumulative" reading of 
Room can be the most interesting. I would prefer to say: shattered slabs are an element of the grave and arctic landscape as well, participate in both imaginary orders and - remaining in this double implication - describing a condition of the protagonists of the erotic plot; in other words, the casual couple in next room. Destroyed graves, breaking ice cover, lovers trying to unite in a sexual act - each of the mentioned images becomes "tightened" by the eighth line. It is an especially active line, which explores all of the sixth stanza and proves itself important in absorbing attributes or "saturating" them.

Now, we can answer more precisely and clearly the question of what is happening in the dark hotel in the city of Wroclaw having experienced - I hope! - a moment of actual focus on the text. The answer is as follows: the work of erotic and of poetics grapples with (each as much as it can) the problem of spreading nonuniformity. Or in other words: the work of erotic and of poietics is (each one in its most appropriate way) an attempt to integrate, unify and build bonds. What is important in both actions, this one erotic and that one linguistic, are shown as physical operations, demanding an energy input and output. "Bed is creaking", "how am I supposed to bear" - these expressions emphasize quite clear "functional" character attempts taken on both sides of the hotel wall. Nonetheless, the first stanza, which we have read as a grotesque epiphany of mediocrity, disintegration, crisis of material, in its further course allows it to be read as a poem about effort and attempt. The earth is rolling, in the rolling earth a couple of casual, one night standers try to reach their apotheosis of sexual intercourse. The moving, straining language of the poet, which is internally loosened and aspires to reconciliation, tries to describe the rolling earth and striving lovers. (Furthermore, one could add that: by this "effort" of the text proceed the efforts of the commentator, who tries to describe what happens in the poem).

The situation which is being described could be commented on in the spirit of optimism: a world where there is some effort and action, does not have to be a completely hopeless world. Exactly in this place, against the overwhelming-apathetic initial of the poem with its density of motifs of consumption, decay, inertia, emptiness, darkness, mediocrity, there is hope that could give rise to positive effects. Even if it happens, if hope (for the couple behind the wall, for language, the poetic subject, the world, the reader) arises in any moment of this poem, it is only to fail.

The last line of the sixth stanza - as I have tried to show, is particularly active,_demonstrating a considerable coalition - brings also a disturbing and sinister accent. As the lovers behind the wall are compared to "shattered slabs", if "shattered slabs" are associated with destroyed tombstones and ice floes, one cannot help but notice a catastrophic harbinger. Whether the world described by such analogies, metaphors and associations can be the world of good fate, fullfilled hope, harmony? In the subsequent, seventh stanza doubt becomes a surrendering reconaissance. Since the subject of this stanza is fiasco or failure. 


$\begin{array}{ll}\text { Bęben i trąba } & \text { [Drum and horn } \\ \text { Przez megafony } & \text { through megaphones } \\ \text { Słuchali oddech } & \text { They listened to the breath } \\ \text { Ziemia się toczy } & \text { The earth is rolling } \\ \text { I nie zdołali } & \text { And they did not manage } \\ \text { Nie będzie siły } & \text { There will be no strength } \\ \text { Ciężka jak serce } & \text { Heavy as a heart } \\ \text { Żeby udźwignąć. } & \text { To bear.] }\end{array}$

This time, the most conjunctive, the most mobile phrase seems to be the line "There will be no strength". It can be connected syntactically and logically with the previous line, referring undoubtedly to the erotic failure from behing the wall. We are given then the lesson: "And they did not manage, there will be no strength". "Stength", which was missing (in the hotel, in Wroclaw, in an imagined world, thought by "self" presented in the poem) is here where "the strength which joins men and women / In Shakespearean animal with two backs", strength of intellect, pure tryumphant biology. Its deficiency means that in the world engulfed with disintegration and mediocrity, in the world of "ruins" and "worn pavements" even the most basic, physically-corporal interpersonal connection seems to be unable to give rise to a new life even potentially. At the same time, there is a possibility of different readings of the seventh stanza which reveals more distant and masked correspondences: "There will be no strength [...] to bear the earth, which, rolls [...] heavy as a heart". Accepting this option (and remembering about the reading, where "bearing the earth" means its "describing") we are given a different interpretation: "strength", which "there won't be" is a syntactic power, an ability to establish new interverbal connections, inspiring representations of the world, showing paralinguistic reality. Once again, it should be noticed that the Miłosz's poem has the most interesting meaning if we agree on the simultaneous launch of both reading options, when, in other words, in the seventh stanza we recognise a kind of syleptic knot: the phrase "there will be no stength" participates at the same time in two syntactic orders and two plot lines, erotic and metapoetical.

Therefore, both efforts, both "strength expenditures" fail because in both situations reservoirs of strength prove overly shallow and insufficient. There will be no strength neither "for them" (a couple of unsuccessful lovers), nor "for me" (unsuccessful poet, trying unsuccessfully to "carry" an excessively heavy earth), nor for language (in which it was not possible to create a coherent, integral representation of reality), nor for the Earth (which remains inexpressible and unrenovated, unintegrated with erotic and language, disintegrated in a corporal order of biology and symbolic order of culture). The last stanza of Room confirms this catastrophic reconnaissance, introducing a motif of weakened (self) consciousness of poetic subject, a motif of death, dissintegration, consumption. 
Nie wiem czy litość

Nie wiem czy miłość

Zamarzła brzoza

Łóżko nie skrzypi

Bądź mi do końca

Połowa wieku

Ciężka jak serce

Starte chodniki.
[I do not know whether pity

I do know know whether love

Frozen birch

The bed is not creaking

Be thou until the end

Half of the century

Heavy as a heart

Worn pavements.]

Among the eight final lines, there are five, which seem to be a repetition of the previous lines. "Frozen birch" and "heavy as a heart" are duplications of the sixth stanza, "bed is not creaking" is a negated form of the formula from the second and third stanza, "half of the century" came from the fourth stanza. It is the third use of the phrase "worn pavements", which previously was used in the first and second stanza. It looks as if a monologue (and the poetic subject standing for it) was not able to free itself from the importunity of several intense, endlessly returning phraseological and image clichés. The returnness can be read as a sign of constant idleness, unresolved, leaving a disturbing topic. The helplessness of the exhausted lovers, who persist in taking more attempts to reach their culmination, corresponds in a metapoetic plan to the helplessness of syntactic repetition that multiplies lines and stanzas but does not bring any conclusion, a punchline, or a decision and cannot establish a final lexical configuration.

As the last line resounds, we lose sight of the casual couple, one night standers described in the poem, which stops talking to us, breaks off, becoming a silent, white and empty sheet of paper. The bed is not creaking. Language is not working. Before it happens, for a moment until the lovers and the poem disapear, we manage to know that an intensive effort was not rewarded with any conclusive result; that what had been started was not finished; that what had been intended - was not achieved. As if in spite of a final spell "be thou until the end", the end does not happen - apparently it is the end understood as closing, recapitulation, filling.

The simple thing of the disappearance, the silence of the poem is not irreversible. It is enough to reread it, from the first to the last stanza, resume the effort of reading to immerse oneself in the movement of generated meanings. To such an undertaking the reader is encouraged by the bridge effect: the last line of the last stanza, "worn pavements", is the last line of the initial stanza as well. It can be viewed as an invitation to rereading. It means consenting to cover the same ground from the description of the hotel in the first stanza to phrases edited in the last stanza, in other words, from a grotesque epiphany of the mediocrity and decay of the constructive impasse. The poem works as if it was a trap which closes the reader in persistent thinking about inability and a lack of strength, of non-fulfilment and imperfection. 
Another concern is that it is worth falling into the trap because each capture can appear to be an interesting reading adventure. Rereading is an opportunity to notice and comment on previously overlooked nuances of the poem, to use so far unused connotations to phrase new speculations.

Room - why that title? Why not Hotel? This question, although it might seem patently absurd (every poem could be titled in a different way that it is), enables us to pay attention to a potential ambiguity of the eponymous word (in Polish, the word "pokój" has two meanings: (i) a room, (ii) peace). Or should we read that Room not as a "hotel room" but as "political peace", formed between countries and governments? Post-WWII Wroclaw, where the plot of the poem takes place, was also where the famous Peace Conference of 1948 was held. Does a poem written seven years later, from an emigration perspective, include an allusion to the "peace congress"? Are we dealing here with late irony towards the rhetorical "fight for freedom" - confronted here with a catastrophic historiosophical conviction? So, in other words, is it worth reading the Miłosz's poem in comparison with a poem written by Herbert (Pacific III. On the Preace Conference) a few years earlier?

Or another reflection taken during rereading: why exactly Newfoundland? Why do such geographical realities occur in this poem? One possible reading leads towards the catastrophy of the Titanic, which occurred off the coast of Newfoundland. Miłosz, as the readers of the For Heraclitus series know, was sensitive to the mythology of the ship, which sank in 1912, two years before the outbreak of World War I, and became a symbolic act that inaugurated the twentieth century. Undoubtedly, Room is a poem which reports the crisis, in which the world was in "after war, in the middle of the century". A reference to the catastrophy of the Titanic (hidden, encrypted in a geographical allusion) could be used as a reminder of the bad signs, and worrying predictions, which were soon to be fullfilled ${ }^{11}$.

Finally - the third reading of the poem, is for me the crucial one. The repetition in Room is not purely immanent, not only a recirculation of lexical-phraseological motifs closed in eight stanzas, sixty-four lines. The repetition is also a type of relation, which connects Room with a previous poem, describing a different post-war destroyed city.

Having noticed this matter, it seems evident and extremely clear, striking even, that Room is a repetition of the poem In Warsaw, Rescue is the final chord of the earlier poem. It is not because of repeating the monologue and poetic subject in a post-catastrophic landscape of destroyed urban substance (cf. In Warsaw:

${ }^{11}$ Both interpretive suggestions - this one binding the title of the poem with the Wroclaw Peace Conference and the one assuming alussive potential of Newfoundland - come from Jan Zieliński, reviewer of the book. 
"The red dust of the rubble", Pokój: "smell of the ruin"). It means something more: there are fragments of Wroclaw which oscilliate between quotation and paraphrases of the formulae used in the Warsaw poem.

Let us look at such a comparison:

My pen is lighter

Than a hummingbird's feather.

This burden

Is too much to bear it.

How can I live in this country,

Where the foot knocks against

The unburied bones of kin?
[Moje pióro jest lżejsze

Niż pióro kolibra. To brzemię

Nie jest na moje siły.

Jakże mam mieszkać w tym kraju

Gdzie noga potrąca o kości

Nie pogrzebane najbliższych?]

(In Warsaw, transl. David Brooks)

Huczą kolibry

Popiół popiołów.

Huczą kolibry

Jak mam udźwignąć

Okrągłą ziemię

(Room)
[Humming birds are hooting

Ash of the ashes.

Humming birds are hooting

How am I supposed to bear

the round earth]

Let us repeat. The poem In Warsaw was dated by Miłosz as 1945; Room was given the annotation: 1955 .

There are ten years between these poems and the two quotations, and one can find parallel, similar symbolic operations: "humming birds" are compared with something that easily becomes more specific in a reader's imagination as a symbol of death, extermination. The connection of "humming birds" to "bones" from 1945 finds analogy in the comparison of "humming birds" to "ashes" from 1955. If we read carefully the two poetic excerpts "parallelly", we notice another dimension of similarity: in both lyrically related passages we find a metapoetical reflection. Describing the world "immediately after the war", "in the middle of the century", as carrying (too heavy) a burden.

Marian Stala pointed out that in Wisława Szymborska's collection of poems entitled Here there is a two-time repetition of the formula "end of the world". Then he posed the question and gave an instant response: "Is it possible for an outstanding, clearly constructed poetic volume to repeat such an exceptional expression? I do not believe in coincidence" ${ }^{12}$. Am I supposed to believe in random

${ }^{12}$ M. Stala, Piosenka o końcu świata. Na marginesie tomu “Tutaj” Wisławy Szymborskiej, in: idem, Niepojęte: Jest, Biuro Literackie, Wroclaw 2011, p. 52. 
concordances? Or should I suspect here a carefully elaborated concept by the author, a strategy of autoparaphrase?

The poem from 1945: the poetic subject-the poet sitting in the ruins of the Warsaw cathedral, the poetic subject talking to himself declares that he would prefer to become a poet of joy, happiness but he had to become a poet of trauma and extermination. He does not want to tell this to those killed - but they are to whom he addresses "Two saved words / Law and justice". He described his situation as a situation of compulsion, of condemnation to an unwanted kind of emotionalism:

Nie chciałem kochać tak,

Nie było to moim zamiarem.

Nie chciałem litować się tak,

Nie było to moim zamiarem.
[I did not want to love so

That was not my design

I did not want to pity so

That was not my design]

(In Warsaw, underlined by M.A.) (transl. David Brooks)

The poem from 1955: the poetical subject-the poet renting a room in a gloomy hotel with worn out pavements recalls the killed ("ash of the ashes", "birds on the tombs", "shattered slabs") but he turns to them. His own emotions become opaque, difficult to describe, enigmatic:

Nie wiem czy litość
Nie wiem czy miłość
Zamarzła brzoza
Łóżko nie skrzypi
Bądź mi do końca
Połowa wieku
Ciężka jak serce
Starte chodniki.

Nie wiem czy litość

[I do not know whether pity

I do know know whether love

Frozen birch

The bed is not creaking

Be thou until the end

Half of the century

Heavy as a heart

Worn pavements.]

The mechanism of substituion is set in motion: Room replaces the phrases of the poem In Warsaw, makes an erratum of them. Instead of "I did not want to love so" appears "I do not know whether love", instead of "I did not want to pity so" appears "I do not know whether pity". The replacement of "I did not know" by "I do know know whether..." is vital. The original phrases were rather an expression of an opposition to the romantic role of the poet-guardian of the dead than a declaration of its unintentional fulfilment ${ }^{13}$. The "repeated" phrases

\footnotetext{
${ }^{13}$ In this way, according to autocommentary by the poet himself, I uderstand the poem In Warsaw. In 1947, in a dispute with Kazimierz Wyka on the volume Rescue and included in it "arcadian elements", Miłosz wrote: "Does not the critic notice an artistic irony, consisting of contradiction: the poet does not want to became a weeper, but he becomes one?"; See: C. Miłosz, List pótprywatny o poezji, in: idem, Zaczynajac od moich ulic, Znak, Cracow 2006, p. 117. Krzysztof Kłosiński
} 
express a deeper disorientation: the poet does not know what links him with the world (just as he does not know whether he is connected to the world itself, an uncertain result due to the conjunctions in language which are supposed to tell about the world). I should say it simply and emphatically. The poem from 1945 designs a situation of miserable necessity: the poet could (and should, and would like to) write poems about "humming birds", the poet writes (although he should not, although he would not like to) poems about "unburied bones". The poem from 1955 replaced the miserable necessity with miserable inability: the poet cannot write either about "humming birds" or "ashes"; between the "hooting of humming birds" and "too heavy earth", between intention and fulfilment there is scarcely a place for a broken attempt that was not successful ${ }^{14}$.

I'm reminded here of a rhetorical question...

What would be life if there had been any repetition? Who would like to be a blackboard, on which time all the time writes different words, or the tombstone of the past? Repetition is a reality and seriousness of being. Whosever has chosen the repetition, matures in seriousness ${ }^{15}$.

It is a lofty afirmation of the repetition delivered by (nomen omen) Constantin Constantinus, the protagonist and the narrator of the famous Soren Kierkegaard treatise. The quoted work became a founding text, canonical for the twentieth century poetics, aestetics, anthropology of repetition; his "creatively treacherous" readers were after all (each of them in a different way) Freud, Lacan, Heidegger, Derrida and Deleuze ${ }^{16}$. Miłosz presented his own, optimistic philosophy of repetition in the poem aimed at Mieczysław Jastrun, published for the first time in 1953. The final phrase of that work was "You know: poet lives with repetition" and means as follows: writing, creating, we participate in a bigger than us, stronger than us order of tradition. Then, repetiton became - somewhat similar as for the Dane - a constructive principle of being, both renewing and maintaining continuity, identity. Miłosz's will and affirmation of repetition was perfectly

looked at a complicated status of the phrase about "weeper", cf. Mnemosyne. Motyw "placzki żałobnej" u Miłosza, in: idem, Poezja żalu, "Śląsk", Katowice 2001, pp. 143-153.

${ }^{14}$ It is worth adding: Room contains elements relatively rare in Miłosz's poetry, a variant of "polyphony" or "intertextuality" - videcilet: autoquotation, autoparaphrase. Stanisław Barańczak wrote about the relative rarity of such "direction to his own speak" in Miłosz, giving as an example of polemic repetiton of the phrase from The Gates of the Arsenal in the poem Where the Sun Rises and Where it Sets, cf. Jezyk poetycki Czesława Miłosza, in: Poznawanie Mitosza: studia i szkice o twórczości poety, vol. 1, J. Kwiatkowski (ed.), Wydawnictwo Literackie, Cracow 1985, p. 434.

${ }^{15}$ S. Kierkegaard, Powtórzenie, in: idem, Powtórzenie. Przedmowy, transl. B. Świderski, WAB, Warsaw 2000, p. 19.

${ }^{16}$ A. Melberg wrote about a line of contemporary reading of Kierkegaard as an author of Reptition in the book entitled Teorie Mimesis. Repetycja, transl. J. Balbierz, Universitas, Cracow 2002. 
described by Marek Zaleski, proving that for the author of Where the Sun Rises and Where It Sets repetition is a matter of hope and faith. "Time, reality and poetry are for Miłosz inseparable and their common determinator is a repetition. It is my thesis, which I would like to prove," said the critic, who indeed fulfiled that announcement ${ }^{17}$.

It is all true. However here, in this specific poem from 1955, we deal with a different case: a pessimistic one. The poem repeats a different poem, repeating itself - and bearing witness to the exhaustion and impasse, into which the speaking poetic subject falls, language used by him, the world thought by him. "There will be no strength" - it can be the most important line of the Wroclaw poem of Czesław Miłosz ${ }^{18}$.

This is the way I understand Room - as a poem about impotence. What is more - as a poem which is a rhetorical manifestiation of impotence. In neo-Romantic criticism (though, despite Stanisław Brzozowski, it does not seem interesting for Miłosz ${ }^{19}$ ) appears a distinction between poems which tell about irony and ironic poems, "consisting in a state of being" ${ }^{20}$. Pokój combines those two modalities: inability is a subject of verbalisation and at the same time a structural language attribute.

Lovers behind the wall try to achieve sexual satisfaction. They come as close to each other as one can be close physically, establish cohesion, unity, as if it was

${ }^{17}$ M. Zaleski, Miłosz, poeta powtórzenia, in: idem, Zamiast. O twórczości Czesława Miłosza, Wydawnictwo Literackie, Cracow 2005, pp. 190-210. Jerzy Jarzębski also discussed the similarities between "philosophers of repetition", formulated by Kierkegaard and Miłosz, cf. "Być samym czystym patrzeniem bez nazwy", w: Poznawanie Miłosza 3, pp. 240-241.

${ }^{18}$ In passing, it is worth noticing: erotic unfulfilment is one of the constant topics of Czesław Miłosz's poetry, one can say that size of its sexual apetite corresponds to the size of its sexual insatiability - Aleksander Fiut wrote about it piercingly, See: Moment wieczny. Poezja Czestawa Mitosza, Wydawnictwo Literackie, Cracow 2011 (section Pod znakiem nienasycenia, pp. 226-236). Pokój can be analysed in a line of poems dedicated to the experience of sexual insatiability, defined by the researcher (which as a rule results to be as literal as figurative) - this poem sounds in a very interesting way as a repetition of the pre-WWII Daina, cf. excerpt: "Przelatywali nad ziemią aniołem, / Co miał dwie głowy, czworo nóg i rąk. / A może jednak zabrakło im skrzydeł, / Dlatego rankiem w którejś wiosce spadł".

"They were flying above the earth with angel, / which had four legs and arms. / And perhaps they lacked wings / That is why in the morning in a villege he fell"

${ }^{19}$ Cf. C. Miłosz, Historia literatury polskiej do roku 1939, chapter IX Młoda Polska, section Krytyka i filozofia, transl. M. Tarnowska, Znak, Cracow 1993.

${ }^{20}$ Cf. S. Lack, Sfinks, in: idem, Wybór pism krytycznych, introduction by W. Głowala (ed.), Wydawnictwo Literackie, Cracow 1980, p. 490. 
in defiance of contingency, ephemerality, which marked their space and existence: a hotel is a place of temporariness, a business trip, as a figure of unrooted post-WWII Wroclaw, which is a city of exile. At that moment the language of the poem gets embroiled in an interesting game of dysjunction and conjunction, gaping and attraction: against a background of a loose syntactic structure (erased punctuation!) and weakened logical ties arises a hypothetical possibility of method and structuring.

Nevertheless, these aspirations always remain (in each stanza of the poem and in each following reading of poem) unfulfilled. The lovers come nearer, connecting - but they do not manager to achieve the peak of satisfaction. A monologue which was to be cohesive remained suspended between the perspectives of conjunction and pressures of disjunction, between the intention of showing the world and the inertia of self repeating the text, the pessimistic repetition of the same, persistent motifs. "What is poetry, which does not save / neither nations nor people", "Poet, where is salvation? / Can anything save the earth" - these were the vital questions of Miłosz's poetry in the second half of the 1940s. The world described in Room cannot be saved. It cannot be saved because the force of cohesion - it does not matter: in language or in a body - is too small; it runs out too fast. Unintegrated, unrenewed, neither the work of erotic nor poietics, the world will lie in the state of consumption, mediocrity, ruin. (Im)potence (that is a force which proves to be powerless) was raised to the rank of a philosophical category, a world description category; while (in) coherence (that is: oscillation of the text between coherence and incoherence) became its formal language.

In a few years' time, in a philosophical poem based on a tale about a boy changed into a fly, Miłosz will have coined a bright formula, which pointed to a case described in Room:

Gdybym przewrócił stół, co byśmy spełnili.

Ten akt, nie-akt, bo zawsze potencjalny

[Had I overturned the table what would we have accomplished

That act, a non-act, always no more than potential]

(Transl. C. Miłosz, R. Lourie)

\section{Bibliography}

Barańczak Stanisław, Język poetycki Czesława Miłosza, in: Poznawanie Miłosza: studia i szkice o twórczości poety, vol. 1, Jerzy Kwiatkowski (ed.), Wydawnictwo Literackie, Cracow 1985. Fiut Aleksander, Moment wieczny. Poezja Czesława Miłosza, Wydawnictwo Literackie, Cracow 2011. Franaszek Andrzej, Miłosz. Biografia, Znak, Cracow 2011. 
Jarzębski Jerzy, "Być samym czystym patrzeniem bez nazwy", in: Poznawanie Miłosza, vol. 3, Aleksander Fiut (ed.), Wydawnictwo Literackie, Cracow 2011.

Kierkegaard Soren, Powtórzenie in: idem, Powtórzenie. Przedmowy, transl. B. Świderski, WAB, Warsaw 2000.

Kłosiński Krzysztof, Mnemosyne. Motyw "płaczki żałobnej” u Miłosza, in: idem, Poezja żalu, "Śląsk", Katowice 2001.

Lack Stanisław, Sfinks, in: idem, Wybór pism krytycznych, Wojciech Głowala (ed.), Wydawnictwo Literackie, Cracow 1980.

Ligęza Wojciech, Jerozolima i Babilon. Miasta poetów emigracyjnych, Wydawnictwo Baran i Suszczyński, Cracow 1998.

Markowski Michał Paweł, Słońce, możliwość, radość, Czarne, Wołowiec 2010.

Melberg Arne, Teorie Mimesis. Repetycja, transl. J. Balbierz, Universitas, Cracow 2002.

Miłosz Czesław, List pótprywatny o poezji, in: idem, Zaczynając od moich ulic, Znak, Cracow 2006.

Sawicka Elżbieta, Hopper w Muzeum Thyssen-Bornemisza, "Zeszyty Literackie" 2012, issue 4, pp. 280-282.

Stala Marian, Piosenka o końcu świata. Na marginesie tomu "Tutaj” Wisławy Szymborskiej, in: idem, Niepojęte: Jest, Biuro Literackie, Wroclaw 2011.

Tarnowska Beata, Geografia poetycka w powojennej twórczości Czesława Miłosza, Wyższa Szkoła Pedagogiczna, Olsztyn 1996.

Warszawa Miłosza, Marek Zaleski (ed.), Wydawnictwo IBL PAN, Warsaw 2013.

Wyka Marta, Dom literacki jako imago mundi. Wokót krakowskiego epizodu Czesława Miłosza, "Dekada Literacka", 2011, issue 1/2, pp. 46-69.

Wyka Marta, Miłosz i rówieśnicy. Domknięcie formacji, Universitas, Cracow 2013.

Zaleski Marek, Zamiast. O twórczości Czesława Miłosza, Wydawnictwo Literackie, Cracow 2005.

Mateusz Antoniuk

There Will be no Strength

(In)coherence and (Im)potency

(Summary)

In 1949, Czesław Miłosz spent a few days in Wroclaw, which was still in ruins after WWII. Six years later Miłosz wrote an interesting poem entitled Pokój (The Room) and created a symbolical vision of the city. The article discusses the style and meaning of the poem, and compares it with another (earlier) poem by Miłosz entitled In Warsaw, which also referred to a post-WWII, heavily destroyed city. This comparison reveals the convergences and differences between both texts.

Keywords: Czesław Miłosz, The Room, In Warsaw, post-war poetry 